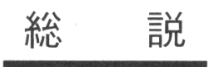

\author{
造粒の基本の基 \\ 武林敬 \\ 株式会社松井製作所 MATSUI wissen 研究所 \\ （テ175-0045＼cjkstart東京都板橋区西台 4-7-2）
}

\title{
Basic Concept for Granulation
}

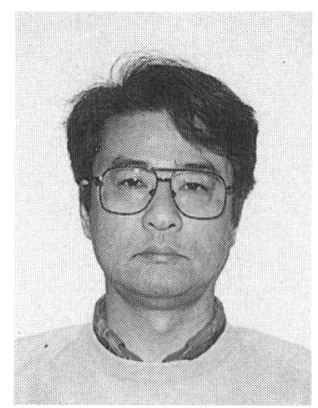

\author{
Kei H. Takebayashi
}

MATSUI MFG. CO., LTD. Matsui wissen

(4-7-2, Nishidai, Itabashi-ku, Tokyo 175-0045)

\begin{abstract}
Field of business in powder handling, it was not directry producted for powders. Because of powder had lots of character, ex. shapes, size distributions and characteristics etc. Therfore, we could not best use of powder's character. Then we granulated for powder and used to object. And it was very easy to handling or next process.
\end{abstract}

In this review, I tried to summarized for fluidized bed granulator.

Key words: granulation, granulating condition, measurements of granulation

\section{1 はじめに}

粉体を扱う業界に打いて，粉体そのものの製品化を行 うことは少ない。その理由として, 粉体特性, 粒径形状 によって，本来必要とされる粉体の持ち味が十分に生か しきれないことが多いと思われる。

一般に粒子は肉眼で 1 個 1 個を容易に識別でき, かつ 形状を球とするほうが取扱いやすい。そのため, 最近で は，「粉体の粒子設計」”「粉体の材料設計」”というよう な新しい考方もでてきている。この考觉を基本として， 粉体という目に見えない領域から，目に見える粒へ形態 を変更させること，つまり造粒について考えてみる。

とくに, 色材に関して, 粉体を単独で商品化すること は, 特殊な場合 (たとえば粉体塗料, 化粧品のような) を除いてあまり見かけない。ただし，色材原料（顔料， プラスチックスなど)では, 粉体を直接取り扱っている。 その場合，上述のように粉体を乥のまま，扱うのではな く, 目的用途に合わせた形に造粒したほうが，ハンドリ ングが非常に容易になる。ここでは，一般的な流動層造 粒乾燥装置を中心に考光方を紹介する。

\section{2 造粒の考え方}

造粒には多くの方法が考元られている。また，同様の 方法であっても, 造粒装置には様々な種類がある。また,
原料についても粉体のほか, 溶液, 奬濁液, 泥しょう, 溶融液, エマルションなどの液体状の場合もある。当然, 原料の状態打よび造粒目的によって適用される造粒装置 は限定される。これらは原料状態, 装置形式, 操作方法, 造粒品の種類などによって分類される。

さらに，造粒品の形態については，ただ単に粒の形状 あるいは大きさばかりでなく, 造粒目的に応じて粒の表 面· 内部の構造, 成分, 量, 反応, 溶解 · 蒸発, 強度, その他の特性などに関連性をもっている。これらの基本 となるのは, 対象原料からどのような造粒品をつくるか という粒子設計思想が必要となる。しかしながら, 造粒 品を想定した場合, まず最初に（1）固体粒子 1 個から なる単一体の粒であるか, またはその粒内が中空, 芯成 分 (液体, 固体) 構造, 結晶形, 異成分複合, 薄膜形成 などの特殊構造かどうか？（2）各種結合様式による 固体粒子の集合体かどうか, または（1）などと同様の 特殊構造のような 2 通りに分類できる。端的に言えば,

（1）は単一体に，（2）は集合体というように言い替光 られる。

ただし，造粒装置・操作方式の観点からは，以上のよ うな形態面でとらえていくと一部重複することもあっ て, 工学的な展開にはかえって不便な場合も多く, 混乱 を起こす。この場合の方法論としては, どのような装置 機械で, 気・液・固（また性成）を取扱い, どのよう 
な機構と操作で目的の粒形態を制御するかを考えると良 い。

まず固体十(気または液体) 系の 2 相流という場合を 考えてみる。このような状態は, 装置側にたって考えて みると，気流（たとえば，流動層，噴流層など）や液流 (たとえば, 摚捧層), さらに 2 層流と機械的要素 (羽根, 円板，刃，円筒などの回転体）の組み合わせによる粒子 群と流体の相対的な運動として現れる。そして，このよ うな場合，それぞれ独特の粒子間結合（各種結合媒体添 加，加熱など）の様式により発生する凝集粒子（たとえ ば, フロック，アグロメレート，複合粒子，顆粒，ペレッ トなど）がある。

また, 分散滴 (固体もしくは液体) を使用した分散合 一型の挙動もとで, 滴内の微粒子, 溶質, モノマー, な どを拘束した状態で，合成，重合，晶析，凝集などの機 構により複合粒，カプセル粒，凝集粒などの造粒が行わ れる。以上のような操作における必要条件は，粒子が流 体流動中で完全に浮遊しているという点である。それよ りも粒子濃度が高く, 近接粒子間の相互作用も大きい固 体・気体系または固体・液体・気体系の充填構造のよう な場合では，いわゆる粉体流動，压縮などの粉体レオロ ジーにかかわる操作が造粒に大きな役割を果たす。その ひとつとして転動, 摚抖混合などの粉体流動においては, 典型的な造粒操作（回転パン，回転ドラム，摚找混合な ど）のように加湿（バインダー）に伴う凝集粒（顆粒・ ペレット）の形態制御が行われる。この場合，転動・混 合作用, 加湿・乾燥などの操作条件は, 生成凝集粒の形 態制御性に大きく影響するため，装置・操作の形式とし ては転動, 混合, 加湿, 通気, 乾燥などを併用（たとえ ば，転動流動層など）する機械や操作上の機能化が問題 となる。また，粉体圧縮では打錠，ロールプレスなどに よる錠，ブリケットなどの定型の小成形物が得られてお り，特に医薬品等の錠剤の仕様条件は㛜しい。可塑性の ある粉体については押し出し, 射出などの機構によって 多種多様の成形物が得られている。

造粒は，各業種特有の効果をねらって行われることが 多く，それと同時に学術的あるいは技術的境界領域に属 する問題が極めて多く存在する。しかしながら，各種の 素材を対象にして，粉体という目に見えないものから目 に見える形をつくるという点では共通である。それゆえ，
多様な技術的手法を模索しながら，より適切な形態を目 指すことが重要な課題であろう。

\section{3 造粒の基礎的考え方}

造粒と乾燥は表裏一体をなしている。それゆえ，造粒 と乾燥の理論的根拠を知っておくと装置のハンドリン グ，時間，経費等の管理が容易になり便利である。造粒 には一部の方法を除いてバインダーが必要である。その ため, 用いる装置によって加液方法や液量は異なるが, いずれの場合も根底に造粒と乾燥理論をおいた上で操作 するべきである。操作の方法によっては，造粒と乾燥の 時間を速めたり，ある条件下のみで起こるトラブルを回 避することも可能となる。色材（化粧品，塗料あるいは インキのような色を目的とする材料）の場合は熱や水分 で変質や色むらが発生したり，メイラード反応で褐変， 熱軟化するなど敏感な成分を多く使用することがある。 ゆえに，造粒方法や乾燥条件の設定には十分な注意が必 要である。ここでは，造粒作業にあたっての基礎理論， およびューティリティの簡単な計算方法を紹介する。

\section{A 固体 液体充填構造}

粒子 水系の充填構造は水分の増加にしたがい，無水 (Dry) $\rightarrow$ 奬垂水 (Pendular) $\rightarrow$ 索状水 I (Funicular I) $\rightarrow$ 索状水 II (Funicular II) $\rightarrow$ 毛管水 (Capillary) $\rightarrow$ ス ラリー (Slurry) と移行していく。Funicular II と Capillary 境はパサパサ領域がネバネバ領域へ移行する 点で「可塑限界」(Plastic Limit), Capillaryと Slurry の境はネバネバがドロドロになる点で「液化限界」(LL) と呼ばれる。可塑限界量は個々の物質によって異なり, 造粒時のバインダ一量を決定する上で重要である。これ らの模式的考え方を Fig. 1 に示す。混合物はそれぞれ の固液量（この場合は粉体・バインダ一量）( $P L$ 量) の重量比で求める。たとえば，医薬品で-.般的に用いら れている乳糖・コーンスターチ・アビセル（バインダー の一種) (8:1:1) を造粒する場合, 可塑限界量はそれ ぞれ $0.18 \mathrm{ml} / \mathrm{g}, 0.67 \mathrm{ml} / \mathrm{g}, 1.23 \mathrm{ml} / \mathrm{g}$ であるから,こ の混合物の $P L$ 值は,

$$
\begin{aligned}
P L & =\frac{8}{10} \times 0.18+\frac{1}{10} \times 0.67+\frac{1}{10} \times 1.23 \\
& =0.334(\mathrm{ml} / \mathrm{g})
\end{aligned}
$$

となる。押し出し造粒や破砕装置の練合機摚找造粒では,

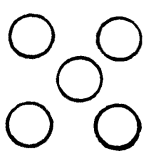

Dry

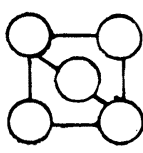

Pendular

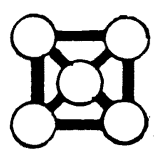

Funicular I

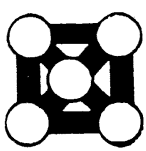

Funicular II

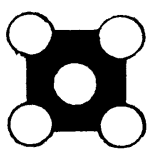

Capillary

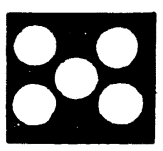

Slurry

'Dry $\stackrel{\longleftrightarrow \text { Plastic limit }}{\longrightarrow}$ Viscous

Fig. 1 Packing Structure of Particle/Water. 
液の総使用量が $P L$ 量とほぼ一致する。

未知の混合物の可塑限界量を知る簡単な方法は, 一定 量の混合物をボウルにはかり，メスシリンダーからバイ ンダーを少量ずつ滴下しながら手圧により練合する。手 で固めると塊状となり, 指でほぐすと崩れる状態まで加 液する。さらに加液していくと粘土状になる。このとき の臨界点をグラム当たりに換算した值がこの混合物の可 塑限界量である。ただし, ダイラタンシー性のある粉体 はこの方法では測定しにくい。

B 造粒のメカニズム

Fig. 2 は液架橋による造粒モデルを示している。

粉と粉との間にバインダーが介在すると, 図中 Aの 液体架橋が形成される。このとき, 液体膜内に負圧吸引 力と液膜の表面張力がはたらく。

これが造粒の際の「凝集」(Agglomeration) である。 2 個の球形粒子にはたらく負圧吸引力の強度 $\left(F_{1}\right)$ およ び表面張力の強度 $\left(F_{2}\right)$ は基本的に次式で表わされる。

$$
\begin{aligned}
& F_{1}=6(1-\varepsilon) \frac{\alpha}{d} \ldots \ldots \\
& F_{2}=\frac{(1-\varepsilon) K}{\pi} 2.2 \frac{\alpha}{d}
\end{aligned}
$$

粒子凝集力 $=F_{1}+F_{2}$.

$K$ : 粒子の接触個数計数

$\varepsilon:$ 空隙率

$\alpha$ : 表面張力
A
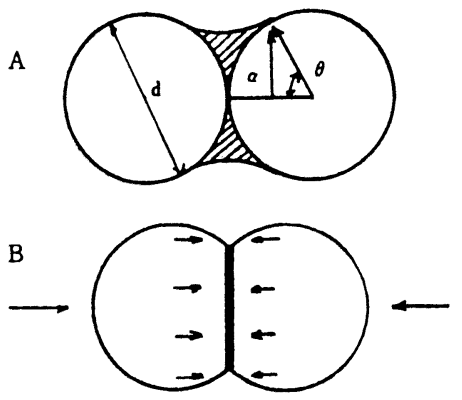

Fig. 2 Granule Model for Liquid Bridge.

\section{$d$ : 粒子径}

（1）と（2）式より以下のことが明らかである。

（a）造粒前の粒子（d) は細かいほど固い造粒物と なる。

（b）空隙率 $(\varepsilon)$ が小さくなるような粒度分布の粉 体を造粒すると，固い造粒物となる。

（c）転動させながら（外圧を加えながら）造粒乾燥 すると (図中 B), 大粒子間隙に小粒子が入り込み, あるいは圧密されて密度の大きい造粒物となる。

C 造粒・乾燥プロセス

造粒・乾燥操作を行なうために湿度図表の見方を知っ ていると便利である。流動層造粒乾燥の場合は空気とバ インダーを使用するので湿度罒表からの条件設定が必要 となる。Fig. 3 は低温度湿度図表である。この罒は,

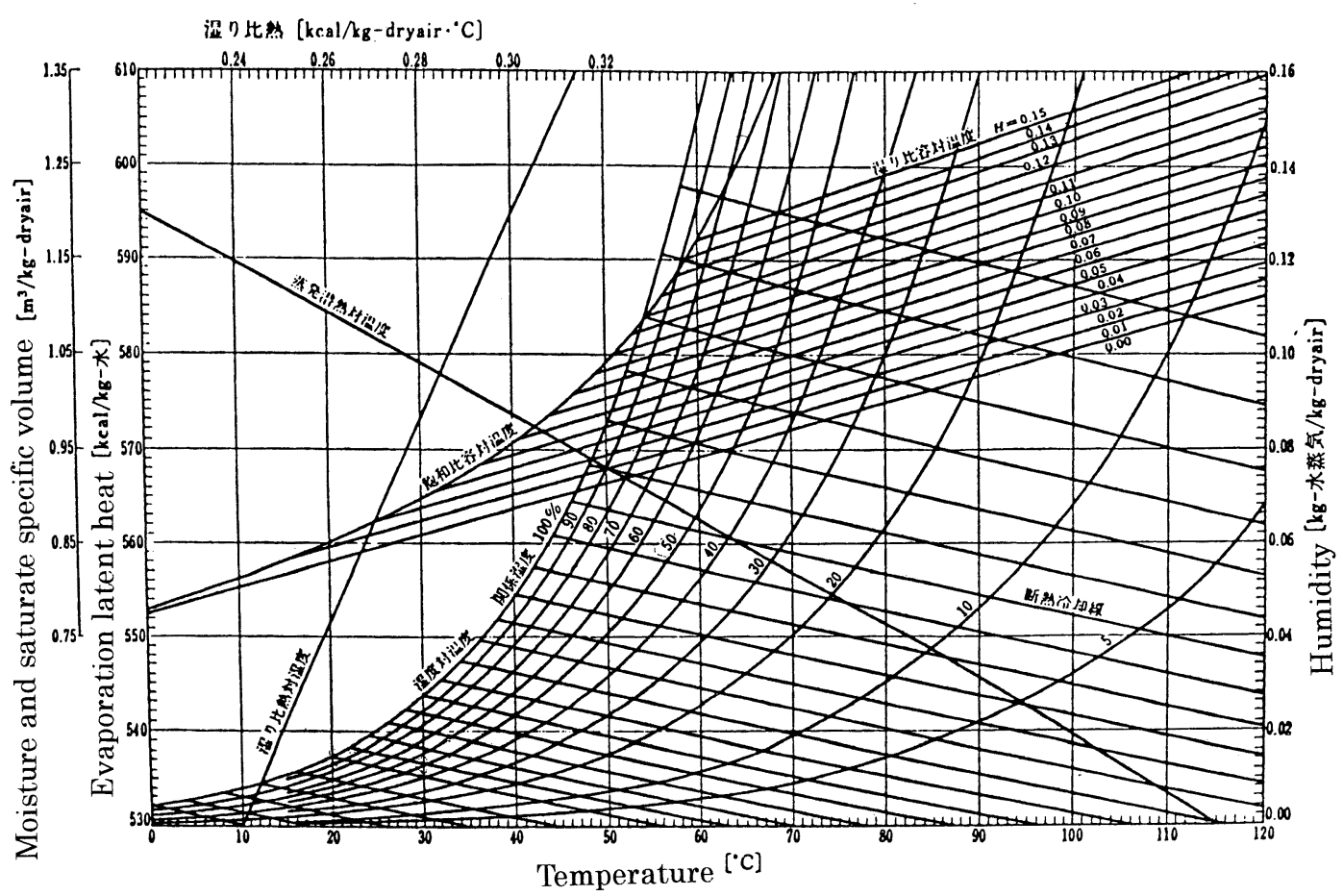

Fig. 3 Chart of Low Temperature and Humidity. 
温度と湿度の関係を示している。一般に湿度という言葉 は, 通常, 相対湿度をいうことが多い。この図は, 相対 湿度と絶対湿度の関係も示している。

(1) 乾湿球計

われわれが湿度を測る手段としてよく用いるものに， 乾湿球がある。乾湿球計の基本的原理を今一度復習して みると以下のようになる。2 本の温度計の一方の水銀球 あるいはアルコール球をガーゼで包み, 水で濡らしてお くと温度差が生じる。このときの $t$ を乾球温度, $t_{W}$ を湿 球温度という。Fig. 4 に, この状態を示している。常に, $t>t_{W}$ である。この湿球温度計では, 空気が蒸気で飽和 していないかぎり水は絶えず蒸発する。このとき蒸発潜 熱（気化熱）が奪われるので水の温度は下がる。水の温 度が下がると空気から水への伝熱(顕熱と潜熱の移動) が始まる。やがて蒸発速度と伝熱速度が動的平衡に達し, 水の温度は一定となる。(実際には水の蒸発は起こって いるし, 空気から水への顕熱移動も起こっている。こ こ のときの温度 $t_{W}$ が初めの空気の湿球温度である。湿球 温度は造粒物乾燥中の恒率乾燥速度期間における排気温 度および品温（層内の製品温度）にほぼ一致している。

\section{（2）断熱冷却温度}

つぎに, Fig. 5 に示すような断熱容器内で温度 $t$ 湿 度 $H$ からなる空気を多量の水に接触させたとする。温 度差により空気から水に伝熱され空気の温度は下がる。 一方, 水は蒸発して湿度が増え,やがては飽和状態となっ

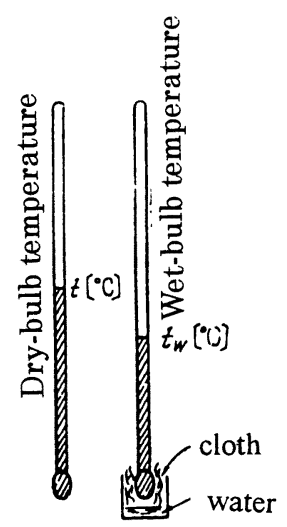

Fig. 4 Dry and Wet Bulb Temperature.

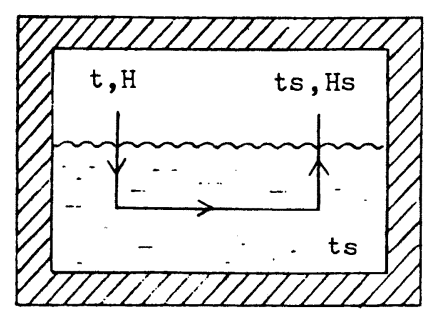

Fig. 5 Adiabatic Cooling.
て静的平衡に達する。このとき水と空気の温度が $t_{s}$ 飽 和湿度 $H_{s}$ となる。この $t_{s}$ のことを初めの空気の断熱冷 却温度 (断熱飽和温度) といい, 湿度図表 (Fig. 3) の 右下がりの線を断熱冷却線という。この線上の空気につ いての断熱冷却温度は同一である。流動層造粒中の排気 温度および湿度は $t_{s}$ および $H_{s}$ である。

（3）湿度図表の応用

乾湿球計において, 造粒物の乾燥に使用する外気がい ま湿球温度で $22^{\circ} \mathrm{C}$, 乾球温度 $30^{\circ} \mathrm{C}$ とする。Fig. 6 のよ うに $22^{\circ} \mathrm{C}$ の垂線と飽和曲線との交点 $\mathrm{Q}$ から断熱冷却線 にそって右下へたどり, $30^{\circ} \mathrm{C}$ の垂線と交わる点 $\mathrm{P}$ を求 める。この $\mathrm{P}$ 点を通るこのときの相対湿度は $50 \%$ であ る。この空気を加熱して $75^{\circ} \mathrm{C}$ の熱風を乾燥機内に流し たとき, 粒子の表面温度（湿球温度および排気温度）は, この熱風の断熱冷却線が飽和湿度の線と交わったときの 温度 $33^{\circ} \mathrm{C}$ となる (Fig. 7)。

熱で変質する物質で誤解してはならないことは，この ときの物質の温度が $75^{\circ} \mathrm{C}$ ではなく $33^{\circ} \mathrm{C}$ であるという ことである。

（4）乾燥プロセス

造粒が終了すると乾燥行程に移るが, 湿潤粒子の品温 と水分の乾燥の過程は Fig. 8のようになる。

A 期間 (I ：材料予熱期間) は粒子表面の水の温度が, このときの熱風の湿球温度まで上昇する期間である。先 の湿度図表でみると, $22^{\circ} \mathrm{C}$ から $33^{\circ} \mathrm{C}$ になる期間である。 $\mathrm{A} \sim \mathrm{B}$ 期間（II：恒率乾燥速度期間）は乾燥速度が最も

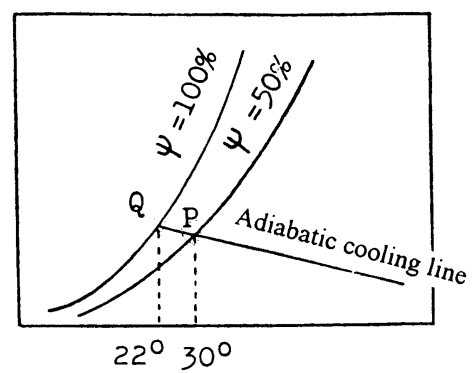

Fig. 6 Relative Humidity.

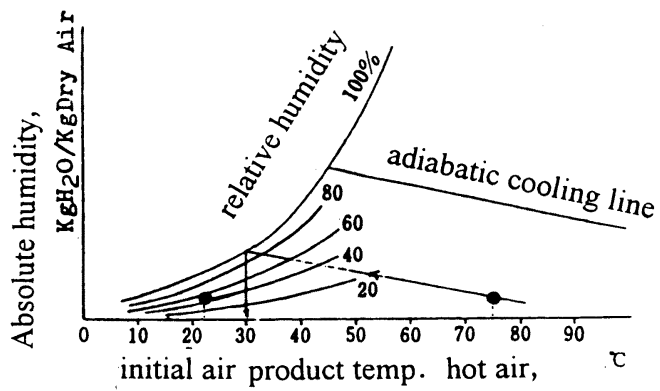

Fig. 7 Dry Air and Product Temperature. 


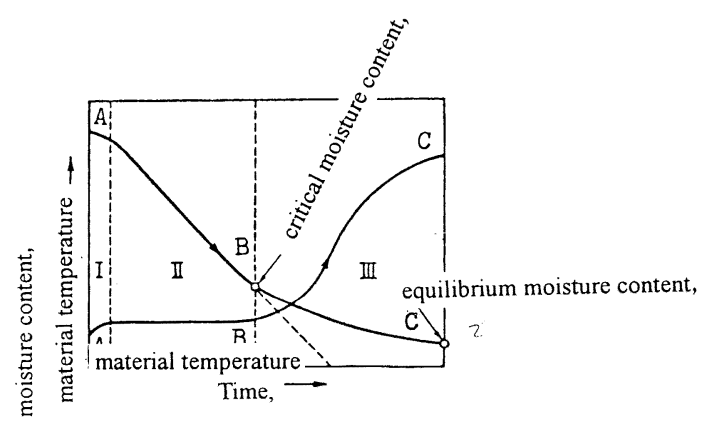

Fig. 8 Drying Velocity.

速く，このときの熱風の湿球温度，先の例では $75^{\circ} \mathrm{C} の$ 断熱冷却線が飽和湿度の線と交わったときの温度 $33^{\circ} \mathrm{C}$ を保っている。なお，造粒が別工程で行われる場合，た とえば押し出し造粒の乾燥機内では $\mathrm{A} \rightarrow \mathrm{A} \sim \mathrm{B}$ と進行 して行くが，流動層造粒乾燥装置ではただちに A B して始まる。 $\mathrm{B} \sim \mathrm{C}$ 期間（III：減率乾燥速度期間）は品 音がしだいに上昇していく期間である。温度が上昇する ということは粒子の表面が水で飽和されなくなったこ と，つまり，粒子表面が乾き始めたことを意味している。 恒率期から減率期に移る B 点は固液充填構造という観点 からみると, 流動層乾燥の場合, Funicular I から Pendular (Fig. 1) への移行点, 湿度図表では断熱冷却 線が, 飽和点から右下がりに移行し始める点で「限界含 水率」(Critical Moisture Content) と言われる。B点か ら温度が徐々に上昇していき $\mathrm{C}$ 点で乾燥は終了する。 この時点は粒子内部から表面へ水分移動速度が表面の水 分蒸発速度よりも遅い。この C の時点では熱風条件と 粒子は平衡状態に達しておりこれ以上乾燥は進行しな い。C 点は「平衡含水率」である。

(5) 乾燥速度

恒率乾燥速度期間の水分蒸発速度 $\left(R_{e}\right)$ は次式で表 される。

$$
\begin{aligned}
R_{e}= & \frac{h \times\left(t-t_{W}\right)}{\lambda_{W}}=K_{H}\left(H_{W}-H\right) \cdots \ldots \ldots \ldots . . . . \\
& R_{e}: \text { 乾燥速度 }\left[\mathrm{kg} / \mathrm{m}^{2} \cdot \mathrm{h}\right] \\
& h: \text { 境膜伝熱係数 }\left[\mathrm{Kcal} / \mathrm{m}^{2} \cdot \mathrm{h} \cdot{ }^{\circ} \mathrm{C}\right] \\
& t: \text { 熱風温度 }\left[{ }^{\circ} \mathrm{C}\right] \\
& t_{W}: \text { 湿球温度 }\left[{ }^{\circ} \mathrm{C}\right] \\
& \lambda_{W}: \text { 蒸発潜熱 }[\mathrm{Kcal} / \mathrm{kg}] \\
& H: \text { 熱風湿度 }\left[\mathrm{kg}-\mathrm{H}_{2} \mathrm{O} / \mathrm{kg}-\text { Dry Air }\right] \\
H_{W} & : \text { 飽和湿度 }\left[\mathrm{kg}-\mathrm{H}_{2} \mathrm{O} / \mathrm{kg}-\text { Dry Air }\right] \\
& K_{H}: \text { 物質移動係数 }\left[\mathrm{kg} / \mathrm{m}^{2} \cdot \mathrm{h} \cdot \Delta \mathrm{h}\right]
\end{aligned}
$$

乾燥速度の最も速い期間は恒率期であることから, こ の期間を長引かせること，すなわち限界含水率を低くす ることが乾燥時間を短くする方法である。装置の面から 考えれば，熱風と粒子の接触面積の大きい流動層乾燥装

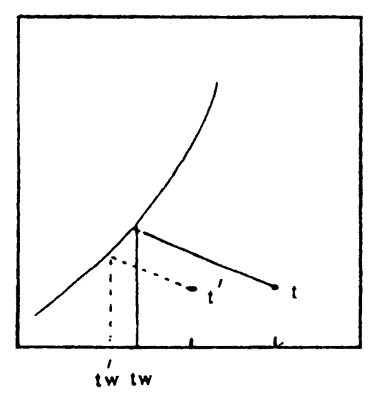

Fig. 9 High-low Temperature.

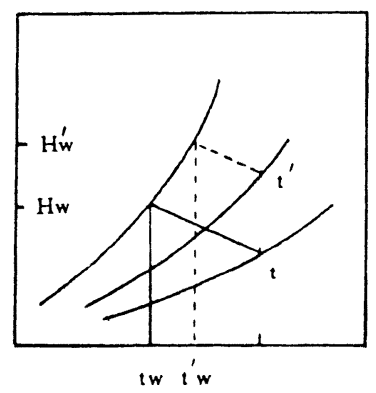

Fig. 10 High-low Humidity.

置 (2〜3\%) 限界含水率が下がるので, 箱型 (20\% 以上) の場合より乾燥時間は短縮できる。

一方, 水分蒸発速度を乾燥温度からみると, 高温 $\left(t-t_{W}\right)$ の場合は低温の場合 $\left(t^{\prime}-t^{\prime}{ }_{W}\right)$ よりその温度差は大きい から乾燥速度は速い (Fig. 9)。また, 同一温度でも高 湿になるほど湿球温度が高くなるから, 低湿 $\left(t-t_{W}\right)$ は 高湿 $\left(t^{\prime}-t^{\prime}{ }_{W}\right)$ より乾燥速度は速くなる（Fig. 10）。し たがって, 乾燥速度を速くする方法は高温で低湿の熱風 を使うことが最も有効となる。

（6）技術面での諸問題

乾燥装置の内壁や設置場所の外気が低温のとき, 急激 に熱風温度を上げると, 水の蒸発量が急に多くなり, 金 属面で露点（Dew Point）に達して結露（水滴発生）す るので注意を要する。露が生じるということは乾燥期内 部の管壁付近の空気が飽和もしくは過飽和になったこと を意味する。結果として, 微粉が管壁に付着するので注 意が必要である。操作方法としては予めウォーミング アップして管壁を暖めたり, 熱風温度を徐々に上げるな どの方法が有効である。

また, バインダーを使った造粒品の乾燥で急激に温度 を上げると, 粒子表面にフィルム膜が形成され乾燥速度 がかえって遅くなる場合がある。水分の蒸発は三次元的 に毛管を伝わって表面から行われるが, フィルム形成は これを妨げることになる。さらに，水溶性の有色成分や 色素を含有する粒子は, バインダーの溶媒の蒸発にとも なって表面に移動し「色むら」の原因となるので, 箱型 
乾燥機の場合はときどきかき混ぜる必要がある。

アルコールをバインダーとした混練物を乾燥する場合 の注意も必要である。エタノールの爆発限界濃度は 3.3 〜19\% (容積率) の範囲である。この範囲内のガスは装 置内で着火エネルギーにより爆発の危険にさらされる。 ハード面ではアース, バグフィルター, 排気ファン, モー ターの選定に注意し, 電気ヒーターを蒸気ヒーターにす るなどの配虑も必要である。ソフト面では爆発限界濃度 以下で乾燥する操作, たとえば初期乾燥でヒーターを OFFにしたり，風量を下げたりすることも有効である。 流動層造粒乾燥では水ーアルコールの割合, 乾燥能力と スプレー量を検討し, 常に爆発限界濃度以下の流動層内 ガス濃度とすべきである。そのときのガス濃度はガス検 知管で測定できるが, 風量, 給排気温度, スプレー量が わかれば容易に計算することもできる。

D ユーティリティ

流動層等の回分式乾燥機におけるユーティリティの簡 略計算法を以下に述べる。これによって，一回の造粒時 間や一日の作業時間及びそれに要した経費の概略をつか むことができる。

(1) 乾燥能力

乾燥能力 $(\mathrm{kg})=$ 風量 $\left(\mathrm{m}^{3} / \mathrm{min}\right) \times$ 空気密度 $\left(\mathrm{kg} / \mathrm{m}^{3}\right)$ X空気比熱 $\left(\mathrm{Kcal} / \mathrm{kg} \cdot{ }^{\circ} \mathrm{C}\right) \times\left(\right.$ 給気温度 $\left({ }^{\circ} \mathrm{C}\right)$ 一排気温度 $\left.\left({ }^{\circ} \mathrm{C}\right)\right\} \times$ 熱効率 $\times$ 時間 (分) $] \div$ 蒸発潜熱 $(\mathrm{Kcal} / \mathrm{kg}$ (水) $)$ 乾燥能力の計算式は流動層造粒の計算式ともなる。流 動層造粒は粉体を乾燥させながら水分を蓄積させ凝集さ せる方法である。スプレーによる加湿と乾燥を同時に繰 り返すことにより, 表面張力と付着力を強くさせ造粒し ていく。上式の計算により，スプレーによる加湿能力が 乾燥能力を上回るよう設定しこれれ一定時間繰り返す。 バインダーの総使用量は粉体の可塑限界前後である。造 粒終了時の保有水分量を可塑限界量の $20 \%$ 程度にする よう乾燥能力を調節する方がよい。

（2）蒸気 代

蒸気代 $($ 円 $)=[$ 風量 $\times$ 空気密度 $\times$ 空気比熱 $\times($ 給気温 度一排気温度 $) \times$ 蒸気製造コスト $\times$ 時間 $] \div[$ 蒸発潜熱 $\times$ 熱交換器効率]

$1 \mathrm{~kg}$ の灯油及び重油の発熱量は $10,000 \mathrm{Kcal} / \mathrm{kg}$ 程度 であるから，その $1 \mathrm{~kg}$ で製造できる有効蒸気量は熱効 率を 0.7 とすると，およそ $12 \mathrm{~kg}$ である。

灯油や重油の $\mathrm{kg}$ 当たりの料金を 70 円とすると 6 円 $/ \mathrm{kg}$ となる。通常, $1 \mathrm{~kg}$ の蒸気製造コストは 6 円として 計算される。

(3) 電気料金

電気代 $($ 円 $)=$ 電動機容量 $(\mathrm{kW}) \times$ 稼働率 $\times$ 時間 $(\mathrm{h})$ $\times 20($ 円 $/ \mathrm{kWH})$

通常, ブロワーやコンプレッサー等の実稼働における 電動機の消費電力はモーターの定格の $75 \%$ としてさし
つかえない。 $\mathrm{kWH}$ 当たりの単価は基本契約量及び冬 . 夏期によって異なるが，20（円/kWH）として計算され るのが一般的である。

\section{4 流動層の圧力損失と風量測定}

空気を用いて造粒乾燥を行う装置の風量や, 風速の管 理は極めて重要である。造粒ではバインダーによる「濡 れ」と熱風による「乾燥」のバランス, すなわち固液充 填構造が決定的な要因である。乾燥は温度と風量によっ て定まるから，風量測定の方法と仕組みの基礎を知って おくと便利である。

ベルヌーイの法則によれば, 流体の機械的エネルギー の総和, すなわち位置, 連動, 圧力の三つのエネルギー の総和は一定である。流れの途中で通路が狭くなれば流 速が速くなり, 運動エネルギーは増加する。総和が一定 であるから，代わりに圧力のエネルギーは減少する。压 力のエネルギーの減少とは圧力が下がることにほかなら ない。造粒乾燥装置に取り付けてある静圧計の変化で空 気の流れぐあいが判定できるので, 圧力の基礎知識も役 に立つであろう。

\section{A 流動層の形成}

金網などの分散板上に粒子を乗せ, 下方より空気を送 入すると粒子は浮かび上がり空気との混相流相が形成さ れる。このときの粒子と空気はあたかも液体が沸騰して いるように流動している。このような状態の層を流動層

(Fluidized bed) という。流動層に粒子を充填し, 空気 を送入すると, 風量の増加にしたがって固定層 $\rightarrow$ 流動 層 $\rightarrow$ 輸送層と変化していく。

（1）固定層 (fixed bed)

分散板 (金網) に送られた空気は整流され，小さな気 泡となって粒子の間隙を通り抜ける。空気量が少ないう ちは粒子は浮かび上がらず固定層としてとどまってい る。しかし, 空気量の増加にともない抵抗が高まり圧力 は降下する。

（2）流動化の始まり（minimum Fluidized velocity, $U m f)$

空気量がしだいに多くなると, ついにある時点で充填 した粒子層の表面が「ブクブク」と動き始める。空気も 小泡となって粒子表面を通過していく。このときが流動 化の始まりである。このときまで圧力は直線的に降下し ていく。

（3）流動層 (Fluidized bed)

ついに粒子は浮かび上がり上下運動をするようにな る。空気量を多くすると浮遊する粒子も高くなる。通常, 流動状態の高さは固定層の高さのおよそ 2 倍程度が適当 である。

（4）輸送層 (Transporting bed)

空気量をさらに多くすると, 粒子の運動はますます活 
発となり，ついにはバグフィルターに張り付いてしまう。 バグフィルターがない場合は装置から飛び出し排気ダク トへと飛び出す。これは, 空気輸送の領域である。

B 圧力損失 $(\Delta p)$

分散板（金網）の真下と流動層の上部を管でつなぎ, U 字形のガラス管 (U字管マノメーター, 後述) 内に 水を封入して空気を流した場合を想定する。(Fig. 11)。 まず空気が金網（スクリーン）を通過するとき抵抗を受 け，圧力が降下する。つぎに粒子層を通過するときも， 粒子の重量に応じて圧力降下する。これを圧力損失とい

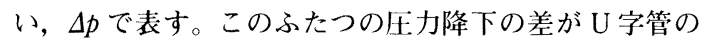
水の高さの差となって現れる（差圧）。粒子を投入しな い状態で測定すればスクリーンの $\Delta p$ が分かり，スク リーンの $\Delta p$ 差し引くか, スクリーンの真上に管をつ なげば流動層の $\Delta p$ を実測することができる。流動層の 压力損失の測定は仕込量やブロアーの能力を決定するう えで重要である。

一方, 固定層 $\rightarrow$ 流動層 $\rightarrow$ 輸送層への移行を圧力損失 の変化でみると Fig. 12 のようになる。

（1）まず投人前のスクリーンの圧力損失であるが, ふつう流動層の $\Delta p$ の $10 \%$ 以上が必要とされている。

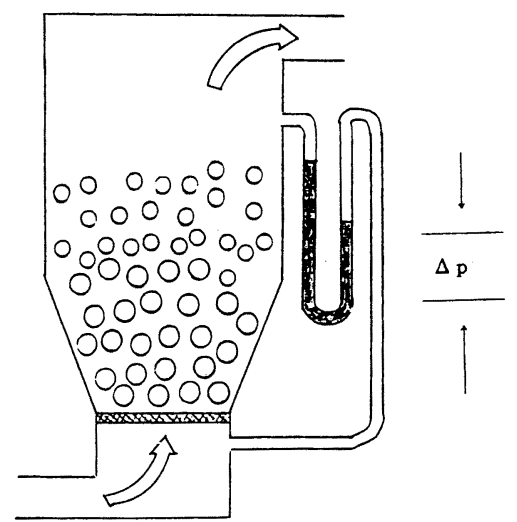

Fig. 11 Measurement Model of Pressure Loss $(\Delta p)$.

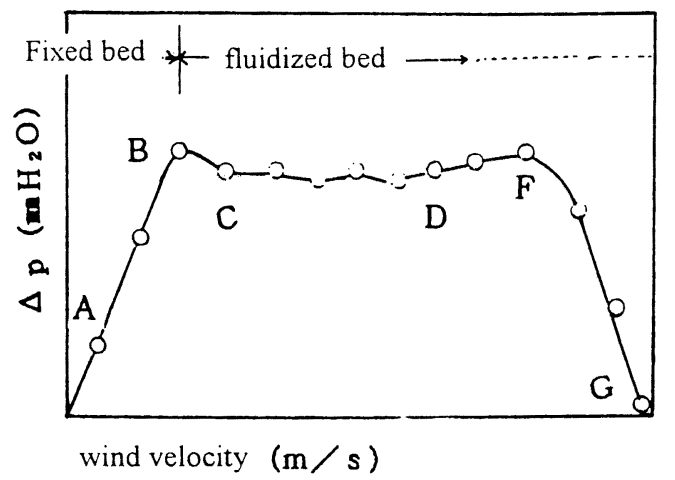

Fig. 12 Pressure Drop in Fluidized Bed.
スクリーンの $\Delta p$ が小さすぎると空気がスクリーン全体 に均一に広がらず，一部分から流れてチャネリング現象 (吹き抜け現象) を引き起こす。したがって粒子全体が 浮かび上がらず正常な流動層を形成しない。

（2）粒子を投入し空気量をしだいに多くすると（風 速を大にすると), 粒子は固定層のままで浮かび上がら ないが $\Delta p$ だけが大きくなっていく $(\mathrm{A} \rightarrow \mathrm{B})$

（3） B 点は先に述べた流動化の始まり (Umf) で流 動層が形成される。流動層が形成されると，いったん $\Delta p$ は下がるが以後は風速を強めても $\Delta p$ はほぼ一定で ある $(\mathrm{C} \rightarrow \mathrm{D})$ 。通常の場合の風速は最小流動化速度 (Umf) の 2 4 倍程度である。

（4）風速をさらに大きくすると粒子の動きは激しく なり $\Delta p も$ 少し大きくなる $(\mathrm{D} \rightarrow \mathrm{F})$ 。ただし, この状 態は正常な運転状態ではない。G は終末速度 $\left(U_{t}\right.$, terminal velocity）で，バグフィルターを付けていなければ 粒子は全部吹き飛ばされてしまい輸送層となる。した がって流動層の $\Delta p$ は消失する。

C 流動層の压力損失 $(\Delta p)$ と仕込量の関係

Fig. 11 の測定モデルに打いて, 空転時のスクリーン (流動床）の $\Delta p$ を求めれば，残りの $\Delta p$ は仕込量との 関係となる。流動層が形成されている間は，風速，粒径 (形), 粒度分布, 塔径の大小にかかわらず圧力損失 $\Delta p$ は粒子径に釣り合うほぼ一定の值であり, 次式が成立す る。

$\Delta p\left(\mathrm{~g} / \mathrm{cm}^{2}\right)=\frac{W}{S}=l f(1-\varepsilon)\left(\rho_{p}-\rho\right)(g / g c)$

$$
\begin{aligned}
W & : \text { 粒子量 }(\mathrm{g}) \\
S & : \text { スクリーンの面積 }\left(\mathrm{cm}^{2}\right) \\
l f & : \text { 仕込高さ }(\mathrm{cm}) \\
\varepsilon & : \text { 空隙率 }() \\
\rho_{p} & : \text { 粒子の密度 }\left(\mathrm{g} / \mathrm{cm}^{3}\right) \\
\rho & : \text { 流体の密度 }\left(\mathrm{g} / \mathrm{cm}^{3}\right) \\
g & : \text { 重力加速度 }\left(\mathrm{cm} / \mathrm{sec}^{2}\right) \\
g c & : \text { 重力換算係数 }\left(\mathrm{g} \cdot \mathrm{cm} / \mathrm{gf} \cdot \mathrm{sec}^{2}\right)
\end{aligned}
$$

ここで,

$$
\text { If }(\mathrm{cm})=\frac{V_{T}(\text { 仕込の容積 })}{S(\text { 面積 })}
$$

$\rho$ は空気の重量で $1.2 \times 10^{-4}\left(\mathrm{~g} / \mathrm{cm}^{3}\right)$ と小さく $\rho_{p}-\rho$ $\doteqdot \rho_{p}$,

$$
g(980) / g c(980)=1
$$

したがって， $(1-\varepsilon)\left(\rho_{p}\right)(5)$ はみかけ密度 $\left[\rho_{p}\right]$ によ く似ており次式に簡略化される。

$$
\Delta p\left(\mathrm{cmH}_{2} \mathrm{O}\right)=\frac{W}{S}=\text { lf }(\mathrm{cm}) \times \rho_{b}\left(\mathrm{~g} / \mathrm{cm}^{3}\right)
$$

D バグフィルターの圧力損失

流動層造粒乾燥装置の全ラインの圧力損失は $\left(\Delta p_{d}\right)$, 
スクリーン $\left(\Delta p_{s}\right)$, 流動層 $\left(\Delta p_{f}\right)$, バグフィルター $\left(\Delta p_{b}\right)$ の総和である。バグフィルター $\left(\Delta p_{b}\right)$ 以外は造粒乾燥中, ほぼ一定である。したがって，造粒中のトラブルの多く はバグフィルターの目詰まりに起因する場合が多い。目 詰まりが起きると空気が流れなくなるので， $\Delta p_{b}$ は上昇 し正常な流動層が形成されなくなる。一定間隔でシェ一 キングやパルスがバグフィルターに与えられるのはこの ためである。

$\mathrm{E}$ 風速・風量測定

（1）U字管マノメーター

$\mathrm{U}$ 字形をしたガラス管に液体を封入 (封液) し, $\mathrm{P}_{1}$, P，の圧力をかけるとHなる液中の差ができる (Fig. 13)。 压力差により液柱の高さも変化するから，この差圧を用 いて風速や風量を測定することができる。これをマノ メーターという。封液は水銀, アルコール，油でもよい が，風量測定の場合はふつう水が用いられる。

（2）ピト一管

Fig. 14 はピトー管にU字管マノメーターを接続した モデルである。いまダクトに密度 $\rho$ の空気を流すと開 口部 Aには圧力 $P$ が現れるが，流机の方向に向けた開 口部 Bには，

$$
P^{\prime}=P+\frac{U^{2} \rho}{2 g c}\left(\mathrm{~kg} / \mathrm{m}^{2}\right)
$$

の圧力が現れる。ここで $U(\mathrm{~m} / \mathrm{s})$ は, B 点の流速であ る。 $P^{\prime}$ を総圧， $P^{\prime}-P$ の差を動圧， $P$ を静圧という。 普通圧力と言えば，静圧のことである。U 字管マノメー ターの式は,

$$
\begin{aligned}
P^{\prime}-P & =\frac{g}{g c}\left(\rho^{\prime}-\rho\right) H \cdots \cdots \cdots \cdots . . . . . . .1 \\
\rho^{\prime} & \text { : 封入した液体の比重 }
\end{aligned}
$$

(8)，(9) 式から

$$
u=\sqrt{2 g c\left[\frac{P^{\prime}-P}{\rho}\right]}=\sqrt{2 g H\left[\frac{\rho^{\prime}}{\rho}-1\right]}(\mathrm{m} / \mathrm{s})
$$

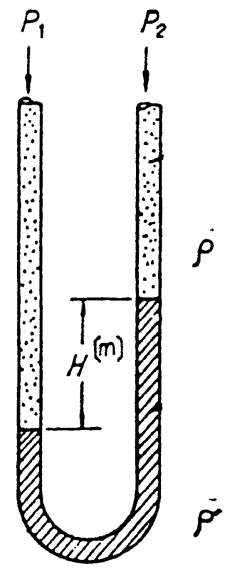

Fig. 13 U Manometer. $\rho^{\prime} / \rho \gg 1$ であるから，ピト一管による風速測定は次式 に簡略化される。

$$
u \fallingdotseq \sqrt{2 g \frac{\rho^{\prime}}{\rho} H}(\mathrm{~m} / \mathrm{s})
$$

（3）オリフィス計

中央に円孔をあけた薄板を直管の途中に挿入して流れ を絞ると，その部分の流速が増し，代わりに圧力が下が る (ベルヌーイの法則) (Fig. 15)。このオリフィス板 の前後の圧力差を測定し，風速や風量を求める方法が才 リフィス計である。

オリフィス計による風量測定は次式により求める。

$$
\begin{aligned}
Q=C A_{0} & \sqrt{2 g \frac{\rho^{\prime}}{\rho}-1 H} \cdots \cdots \\
C & : \text { 流量係数 } \\
A_{0} & : \text { オリフィス孔 } \\
g & : \text { 重力加速度 } \\
\rho^{\prime} & : \text { 封液の密度 } \\
\rho & : \text { 空気の密度 }
\end{aligned}
$$

実用的には，風量 $Q$ の時に差圧が $\Delta h$ になるオリフィ 不板を製作しておけば，差圧が $\Delta h_{1} に$ にったときの風 量 $Q_{1}$ を求めることができる。このときの式は以下の通 りである。

$$
\Delta h_{1}=\Delta h \times\left(\frac{Q_{1}}{Q}\right)^{2}
$$

したがって

$$
Q_{1}=\sqrt{\frac{\Delta h_{1}}{\Delta h} \times Q}
$$

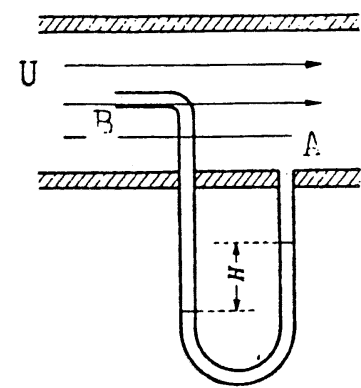

Fig. 14 Pitot Tube.

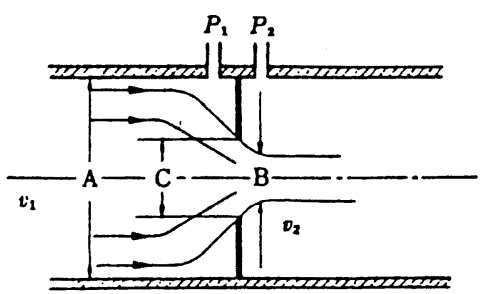

Fig. 15 Oriffice Meter. 
（4）その他

灰力を測る計器ではブルドン管庄力計が一般的であ り，ほとんどの装置に使われている。

1 気圧（1 atm）を0として圧力を測定したものをゲー ジ压といい, 大気庄より高い圧力を正庄, 低い圧力を負 圧という。流動層造粒乾燥装置は通常排気側と給気側の どちらか，もしくは両方にブロアーを装備している。排 気側にブロアーを装備している場合は，管体内部は負庄 となり,給気側にブロアーを装備した場合は正圧となる。 もちろん両側にブロアーを装備した場合は正压にも負压 にもなる。ブルドン管压力計には2 個の接続口があり正 压も負庄測定できるようになっている。

風速を測るものに熱線風速計がある。これは風速によ る熱線の温度を電気抵抗変化によって検出するもので, 計器から風速 $(\mathrm{m} / \mathrm{s})$ をダイレクトに読み取ることがで き便利である。風速は層流の域を測る必要があるため, 測定位置から前後にダクト径の 5 倍以上の直管部が必要 である。この風速とダクト面積から風量を割り出すこと ができる。

直接風量を測定できる計器にロータメータ（rotameter）がある。この装置は日盛り付きのガラス円筒内 に浮子（float）または回転子（rotor）が入っており，
浮力と自重のバランスから風量を読み取るものである。

$$
5 \text { おわりに }
$$

本稿では, 造粒操作技術のほんの一部分に限って解説 を試みた。それゆえ，読者のなかには物足りない感じを おぼえた方もおられると思われる。しかしながら，造粒 操作に詨する基本的な考え方については，言及できたの ではないかと自負している。色材工業における造粒につ いては他に成書があるので参照いただきたい3)。本稿は， 高度な専門知識については触れてはいないが, 実際の現 場ですぐ活用できるような問題点を整理して書いたつも りである。それゆえ，現場において役に立てれば幸いで ある。

(受付 : 1999 年 7 月 6 日, 受理：1999 年 7 月 21 日)

$$
\text { 文献 }
$$

1) たとえば：製剤と粒子設計シンポジゥム講演要旨 集 $(1984 \sim 1992)$ 粉体工学会主催.

2) 荒川, 小石, 角田, 竹内, 伊藤 編, “最新粉体の 材料設計”，1988 年，テクノシステム。

3）（社）日本粉体工業技術協会編，“造粒ハンドブッ ク”，オーム社, 1993 年. 


\title{
日本油化学会誌本号掲載 論文要旨
}

\section{[総説 $]$}

\section{造粒の基本の基}

\author{
武 林敬 \\ 株式会社松井製作所 MATSUI wissen 研究所 \\ ( ₹ 175-0045 東京都板橋区西台 4-7-2)
}

粉体を扱う業界において, 紛体そのものの製品化を行うことは少ない。その理由として, 紛体の特性，粒子形状 および粒子径によって，本来必要とされる紛体なお持ち味が十分に生かしきれないことが多いためと考えられる。 その場合，目的用途に合わせた形に造粒したほうが，ハンドリングあるいは後工程の操作が非常に容易となる。

ここでは，一般的な流動層造粒について解説を試みる。

(連絡者：武林 敬) Vol.48, No.9, 861 (1999)

\section{[報文］リポソームの巨視的状態に及ぼす}

\section{ポリエチレングリコール (PEG) 結合リン脂質の PEG 鎖長の影響}

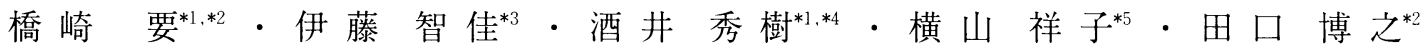
斎藤好廣*2 - 小川尚武 ${ }^{* 2}$ - 阿部 正彦 ${ }^{* 1, * 4}$

*1 東京理科大学理工学部 ( T 278-8510 千葉県野田市山崎 2641)

*2 日本大学薬学部 (干 274-8555 千葉県船橋市習志野台 7-7-1)

*3 日本油脂油化学研究所 ( ₹ 210-0865 神奈川県川崎市川崎区千鳥町 3-3)

*4 東京理科大学界面科学研究所 ( ₹ 162-0825 東京都新宿区神楽坂 1-3)

*5 共立薬科大学 ( ₹ 105-8512 東京都港区芝公園 1-5-30)

ジステアロイル - $N^{-}$モノメトキシー゚゚エチレングリコール - スクシニルーフォスファチジルエタノールアミン (PEG-DSPE)，(PEG-DSPEのPEG 平均分子量は $1000,2000,3000,5000$ および 12 000)の PEG 鎖長がリポソー ムの巨視的状態に及ぼす影響を，リポソーム形成，粒子径，表面電位および分散性の観点から検討した。調整に用 いたジパルミトイルフォスファチジルコリン（DPPC）の量は全てリポソームの形成に使われたが，長いPEG 鎖をも つPEG-DSPEの場合には用いた全ての量がリポソーム形成に使われるのではなかった。リポソーム二分子膜中の PEG-DSPEの濃度は, PEG-DSPEのPEG 鎖長の増加に伴い減少した。PEG-DSPEを含むリポソームの粒子径は, PEG-DSPEのPEG 鎖長の増加に伴い減少した (PEG12000-DSPEを除く)。PEG12000-DSPEの場合には，DPPCリ ポソーム表面に吸着しているようであった。リポソームのゼー夕電位の負の絶対值は, PEG-DSPEの PEG 鎖長の 増加に伴い減少した。PEG-DSPEを含むリポソームの分散性は，ゼータ電位の絶対值の減少にもかかわらず，少 なくとも14日間は保持されていた。 